\title{
Determination of cytokine profile and fecal calprotectin in patients with inflammatory bowel disease of different activity degree
}

\section{Ainur Doszhan, Roza Bektayeva, Aiman Galiyeva, Kapura Adrissova}

Department of Gastroenterology and Infectious Diseases, Astana Medical University, Nur-Sultan city, Republic of Kazakhstan

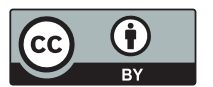

This work is licensed under a Creative Commons Attribution 4.0 International License

Received: 2019-03-15

Accepted: 2019-04-26

UDC: 616.1

\section{J Clin Med Kaz 2019;2(52):23-29}

Corresponding Author: Ainur Doszhan, Department of Gastroenterology and Infectious Diseases, Astana Medical University, Nur-Sultan city, Republic of Kazakhstan. Tel.: 87017709708

E-mail: doszhan_88_88@mail.ru

\section{Abstract}

Aim: To determine the IL-6, IL-8, TNF- $\alpha$ and fecal calprotectin levels in different phases of the disease and correlate their values with the clinical and endoscopic data in patients with inflammatory bowel diseases.

Methods: 41 patients with IBD were selected: $78 \%$ with ulcerative colitis and $22 \%$ with Crohn's disease, $39 \%$ women and $61 \%$ men, mean age $35,3 \pm 1,9$. Ulcerative colitis: acute current $-12,5 \%$, chronic continuous $-6,25 \%$, chronic relapsing $-62,5 \%$, rarely relapsing $-12,5 \%$, often relapsing $-6,25 \%$. Minimal activity $-15,6 \%$, moderate activity $-84,4 \%$. Crohn's disease depending on the Crohn's Disease Activity Index (CDAI): mild disease and minimal activity $55,6 \%$, moderate severity and moderate activity $-44,4 \%$.

Results: IL- 6 was increased to $20,56 \pm 5,51 \mathrm{pg} / \mathrm{ml}$ at ulcerative colitis, to $18,64 \pm 4,70 \mathrm{pg} / \mathrm{ml}$ at Crohn's disease; IL- $8-79,38 \pm 15,37 \mathrm{pg} / \mathrm{ml}$ at ulcerative colitis and $82,49 \pm 34,81 \mathrm{pg} / \mathrm{ml}$ at Crohn's disease; TNF- $\alpha-28,70 \pm 3,24 \mathrm{pg} / \mathrm{ml}$ and $32,32 \pm 6,92 \mathrm{pg} / \mathrm{ml}$, respectively. Depending on the extent of the lesion: for IL-6 at E2 - 23,91 $\pm 14,64 \mathrm{pg} / \mathrm{ml}$ and at E3 - 20,54 $\pm 5,61 \mathrm{pg} / \mathrm{ml}$; for IL-8 at E2 $60,95 \pm 14,60 \mathrm{pg} / \mathrm{ml}$ and at E3 - 97,31 $\pm 24,10 \mathrm{pg} / \mathrm{ml}$.

Conclusion: The results of the study have demonstrated an increase in the concentrations of IL- 6 , IL-8 and TNF- $\alpha$ in patients with ulcerative colitis and Crohn's disease, significantly exceeding the reference values. With increased activity of the inflammatory process, a significant raise in IL-6, IL- 8 and TNF- $\alpha$ level was observed. Determining the level of fecal calprotectin depending on the location of the lesion and the activity of the process confirmed its importance in assessing the extent of lesions of the colon and diagnosing the activity of ulcerative colitis and Crohn's disease in different phases of the disease.

Key words: ulcerative colitis, Crohn's disease, cytokine profile, tumor necrosis factor, interleukins

ӘРТУРЛІ ДӘРЕЖЕЛІ ҚОС НУКТЕНІҢҚАБЫНУ АУРУЛАРЫ БАР НАУҚАСТАРДА ЦИТОКИН БЕЙІНІ МЕН ФЕКАЛЬДЫ КАЛПРОТЕКТИНДІ АНЫҚТАУ

Досжан А.Д., Бектаева Р.Р., Галиева А.Ж., Адрисова К.С.

Гастроэнтерология және жұқпалы аурулар кафедрасы, Астана медициналық университеті, Нұр-Сұлтан қаласы, Қазақстан Республикасы

\section{ТҰЖЫРЫМДАМА}

Бұл жұмыста негізгі экзогенді бүйрек уыттырымен уланған кездегі бүйректің зақымдалу механизмі және нефропатияның дамуы туралы Мақсаты: Ісінудің созылмалы қабыну аурулары бар науқастарда клиникалық және эндоскопиялық көріністермен салыстыра отырып, аурудың әр түрлі сатыларында IL-6, IL-8, TNF- $\alpha$ және фекальдык кальпротектин деңгейлерін анықтау.

Әдістер: Ішек қабыну ауруы диагнозымен анықталған 41 науқас: $78 \%$ жаралы колит және 22\% Крон ауруы, әйелдер $39 \%$ және ерлер $61 \%$, орташа жас 35.3 ะ 1.9. Жаралы колит бойынша: өткір - 12,5\%, созылмалы үздіксіз - 6,25\%, созылмалы қайталама - 62,5\%, сирек қайталанатын - 12,5\%, жиі қайталанатын - 6,25\%. Ең төменгі белсенділік - 15,6\%, қалыпты қызмет - 84,4\%. Бест индекс көрсеткішке байланысты Крон ауруы: жеңіл және төменгі белсенділік - 55,6\%, қалыпты ауырлық және қалыпты белсенділік - 44,4\%.

Нәтижелері: Жаралы колитте жасалған IL-6 20,56 $\pm 5,51$ pg/ml дейін өсті, Крон ауруы кезінде - 18,64 \pm 4,70 pg/ml; IL-8 жаралы колитте - $79.38 \pm 15.37 \mathrm{pg} / \mathrm{ml}$, Крон ауруында - $82.49 \pm 34.81 \mathrm{pg} / \mathrm{ml}$; TNF- $\alpha$ - тиісінше $28.70 \pm 3.24 \mathrm{pg} / \mathrm{ml}$ және тиісінше $32.32 \pm 6.92 \mathrm{pg} / \mathrm{ml}$. 3 ақымдану дәрежесіне қарай: IL-6 үшін E2 - $23.91 \pm 14.64$ pg/ml және E3 - $20.54 \pm 5.61$ pg/ml; IL-8 үшін E2 - $60.95 \pm 14.60$ pg/ml және E3 - $97.31 \pm 24.10$ $\mathrm{pg} / \mathrm{ml}$.

Қорытынды: Зерттеудің нәтижелері жаралы колит және Крон ауруы бар науқастарда IL-6, IL-8 және TNF- $а$ концентрациясының артуын көрсетті. Қабыну процесінің белсенділігі жоғары болған кезде IL-6, IL-8 және TNF-a деңгейлерінің айтарлықтай өсуі байқалды. Зақымданудың орналасуына және процестің белсенділігіне байланысты фрекальдык кальпротектин деңгейін анықтау ишектің зақымдану дәрежесін бағалауда және жаралы колит және Крон аурудың әртүрлі кезеңдерінде диагностикасында маңыздылығын растады.

Негізгі сөздер: жаралы колит, Крон ауруы, цитокин профрилі, ісік некрозының факторы, интерлейкиндер 


\section{ОПРЕДЕЛЕНИЕ ЦИТОКИНОВОГО ПРОФИЛЯ И ФЕКАЛЬНОГО КАЛЬПРОТЕКТИНА У ПАЦИЕНТОВ С}

ВОСПАЛИТЕЛЬНЫМИ ЗАБОЛЕВАНИЯМИ ТОЛСТОЙ КИШКИ РАЗЛИЧНОЙ СТЕПЕНИ АКТИВНОСТИ

Досжан А.Д., Бектаева Р.Р., Галиева А.Ж., Адрисова К.С.

Кафедра гастроэнтерологии и инфекционных болезней, Медицинский университет Нур-Султан, город Астана, Республика Казахстан

\section{PEЗЮME}

Цель: Определить уровень ИЛ-6, ИЛ-8, ФНО- $а$ и фекального кальпротектина в разные фразы течения заболевания и соотнести их значения с клинико-эндоскопической картиной у пациентов с хроническими воспалительными заболеваниями толстой кишки.

Методы: 41 пациент с документально подтвержденным диагнозом В3К: 78\% с язвенным колитом и 22\% с болезнью Крона, женщин $39 \%$ и мужчин $61 \%$, средний возраст 35,3 + 1,9. По характеру течения язвенного колита: острое течение - $12,5 \%$, хроническое непрерывное - 6,25\%, хроническое рецидивирующее - 62,5\%, редко рецидивирующее - 12,5\%, часто рецидивирующее - 6,25\%. Минимальная активность - 15,6\%, умеренная активность - 84,4\%. Болезнь Крона в зависимости от индекса Беста (CDAI): легкое течение и минимальная активность $55,6 \%$, средняя степень тяжести и умеренная активность $-44,4 \%$.

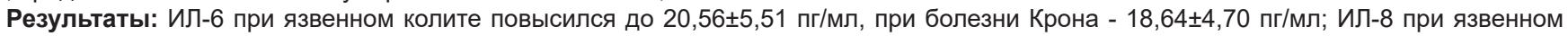

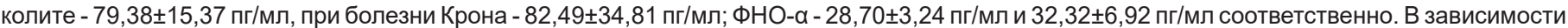

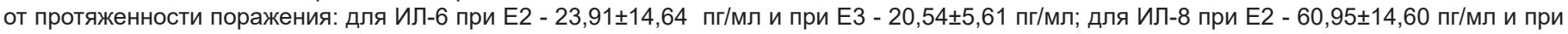

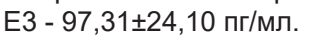

Заключение: Результаты проведенного исследования продемонстрировали повышение концентраций ИЛ-6, ИЛ-8 и ФНО-а у пациентов с язвенным колитом и болезнью Крона, значительно превосходя референтные значения. При усилении активности воспалительного процесса наблюдалось достоверное повышение уровней ИЛ-6, ИЛ-8 и ФНО-а. Определение уровня фекального кальпротектина в зависимости от локализации поражения и активности процесса подтвердило его значимость в оценке протяженности поражения толстой кишки и диагностике активности язвенного колита и болезнью Крона в разные фазы течения заболевания.

Ключевые слова: язвенный колит, болезнь Крона, цитокиновый профиль, фактор некроза опухоли, интерлейкины

\section{Введение}

Данные последнего систематического обзора показали глобальность проблемы воспалительных заболеваний кишечника (ВЗК). В целом, 16 (72,7\%) из 22 исследований с болезнью Крона (БК) и $15(83,3 \%)$ из 18 исследований с язвенным колитом (ЯК) продемонстрировали стабильную или снижающуюся частоту ВЗК в Северной Америке и Европе. Однако в новых промышленно развитых странах Африки, Азии и Южной Америки, включая Бразилию и Тайвань, с 1990 года отмечается рост заболеваемости ВЗК. Хотя заболеваемость в западных странах стабилизируется, бремя болезни остается высоким, поскольку распространенность превышает 0,3\% [1].

За предшествующие десятилетия было проведено значительное количество исследований по изучению патогенеза ЯК и БК, результаты которых позволяют сделать вывод, что ЯК и БК являются разными фенотипами ВЗК. Хотя этиология ВЗК остается до конца неизученной, полагают, что ЯК и БК возникают в результате неадекватной иммунной реакции слизистой оболочки толстой кишки у лиц с наследственной отягощенностью. ВЗК характеризуется преимущественно активацией Тh типа 1, при которой повышается синтез провоспалительных цитокинов: ФНО- $\alpha$ (фактор некроза опухоли), ИЛ-6 (интерлейкин), ИЛ-8, ИЛ1b, ИЛ-12, ИЛ-21, ИЛ-23, ИЛ-17 и т. д. [2, 3, 4, 5, 6].

Среди них ИЛ-6 - плейотропный цитокин, функции которого реализуются во врожденном и в адаптивном иммунном ответе. Синтез ИЛ-6 коррелирует с активацией клеток и обычно сохраняется под контролем глюкокортикоидов, катахоламинов и половых стероидов. ИЛ-6 играет ключевую роль в острой фазе воспалительного ответа, который приводит к STAT3-зависимым изменениям концентраций плазменных белков таких, как С-реактивный белок, сывороточный амилоид А, гаптоглобин, фибриноген, альбумин и трансферрин [7].

Одним из наиболее активных провоспалительных цитокинов является ФНО- $\alpha$. Он оказывает плейотропное действие посредством экспрессии молекул адгезии, пролиферации фибробластов, прокоагулянтов, а также инициирует цитотоксические, апоптотические процессы. Данный мембранный белок также обладает способностью увеличивать продукцию ИЛ-1 $\beta$, ИЛ-6 и ИЛ-33. Уровень
ФНО- $\alpha$ в сыворотке коррелируют с клинической активностью ЯК и БК $[8,9,10]$. Его роль в воспалении толстой кишки легла в основу разработки биологической терапии для пациентов с ВЗК, а именно ингибиторов ФНО- $\alpha$, блокирующих провоспалительный цитокин ФНО- $\alpha$.

ИЛ-8являетсянизкомолекулярнымпровоспалительным цитокином и играет роль хемоаттрактанта для нейтрофилов, макрофагов, лимфоцитов и эозинофилов. Он вызывают миграцию нейтрофилов и базофилов в очаг воспаления и их дегрануляцию, выделение супероксидного радикала. У здоровых людей в сыворотке крови ИЛ-8 выявляется крайне редко [11].

Изучение роли цитокинов в иммунорегуляции имеет большое значение для понимания патогенеза ВЗК. Обзор литературы за последние десять лет не дает конкретных результатов, демонстрирующих доказанную взаимосвязь между значениями маркеров активности воспалительного процесса и клинико-эндоскопических индексов активности заболевания. Уже в течение длительного времени идет поиск простых инструментов оценки течения ВЗК, среди которых широко изучаются сывороточные цитокины. До сих пор остаются открытыми вопросы о динамике цитокинового профиля при различной степени тяжести ЯК и БК $[12,13$, $14,15]$.

Актуальной является также использование диагностических методов, которые отличаются неинвазивностью, быстротой исполнения, доказанностью в оценке состояния кишечника. Наиболее часто используемым параметром для мониторинга активности заболевания является фекальный кальпротектин (ФК). В последнем пересмотре Европейского общества по изучению БК и ЯК (European Crohn's and Colitis Organisation, ЕССО) ФК рассматривается как высокочувствительный маркер воспалительного процесса при ВЗК. Уровень ФК коррелирует с эндоскопической активностью заболевания, поэтому очень важен при разнообразных клинических ситуациях, включая первичную дифференциальную диагностику, диагностику рецидива и оценку ответа на лечение (УД 2b, СР В) $[16,17]$. 


\section{Цель исследования}

Определить цитокиновый профиль и уровень неинвазивного маркера фекального кальпротектина и сопоставить их значения с клинико-эндоскопической картиной у пациентов с хроническими воспалительными заболеваниями толстой кишки.

\section{Материалы и методы исследования}

Нами был обследован 41 пациент с документально подтвержденным диагнозом ВЗК, поступивший на стационарное лечение в Центр колопроктологии и хирургической инфекции ГКП на ПХВ “Городская больница №1” акимата г. Астаны. Все пациенты подписывали информированное согласие на участие в клиническом исследовании.

Из 41 включенного в исследование пациента, 78\% $(n=32)$ составили пациенты с ЯК и 22\% (n=9) с БК. Распределение по полу и возрасту было следующим: женщин было $39 \%(\mathrm{n}=16)$ и мужчин - $61 \%(\mathrm{n}=25)$ в возрасте от 22 до 62 лет, средний возраст $35,3 \pm 1,9$ (Таблица 1).

Таблица 1 Характеристики пациентов, участвовавших в исследовании

\begin{tabular}{|l|l|l|}
\hline Характеристики & $\mathrm{n}$ & $\%$ \\
\hline Пол & & \\
\hline • Женский & 16 & $39 \%$ \\
\hline • Мужской & 25 & $61 \%$ \\
\hline \multicolumn{2}{|c|}{ Возраст, средний возраст $\pm \mathrm{m}$} & \multicolumn{2}{|c|}{$35,3 \pm 1,9$} \\
\hline
\end{tabular}

По характеру течения среди пациентов с ЯК острое течение было выявлено у 4 пациентов (12,5\%), хроническое непрерывное - 2 (6,25\%), хроническое рецидивирующее - 20 (62,5\%), редко рецидивирующее - 4 (12,5\%), часто рецидивирующее - 2 (6,25\%). При оценке клинической степени активности заболевания были получены следующие данные: минимальная активность (ИМ от 3 до 5 баллов) 5 пациентов (15,6\%), умеренная степень активности (ИМ 6-10 баллов) - 27 (84,4\%).

Среди пациентов с БК наблюдалось следующее распределение в зависимости от значения индекса Беста (Crohn's Disease Activity Index, CDAI): легкое течение и минимальная степень активности у 5 (55,6\%) больных, средняя степень тяжести и умеренная активность - у 4 (44,4\%). Нестенозирующая, нефистулизирующая форма заболевания В1 - 4 (44,5 \%) пациента, стенозирующая В2форма - 3 (33,3\%), фистулизирующая В3 - 2 (22,2 \%).

Уровень цитокинов определяли с помощью набора реагентов для иммуноферментного определения концентрации цитокинов в сыворотке крови, разработанных
Диагноз устанавливали на основании данных клиникоинструментальных и лабораторных исследований согласно клиническому протоколу. Критерии исключения: прием иммунодепрессантов и проведение химико-лучевой терапии перед определением цитокинов и фекального кальпротектина.

Для определения локализации поражения различных отделов кишечника у больных ЯК и БК были проведены колоноскопия, эзофагогастродуоденоскопия с гистологическим исследованием биопсийного материала (Таблица 2, 3).

Таблица 2 Частота поражения различных отделов толстого кишечника у больных с ЯК

\begin{tabular}{|l|l|l|}
\hline \multirow{2}{*}{ Протяженность } & $\mathrm{n}=32$ \\
\cline { 2 - 3 } & $\mathrm{n}$ & $\%$ \\
\hline Проктит (Е1) & 3 & 9,3 \\
\hline Левосторонний колит (E2) & 11 & 34,4 \\
\hline Тотальный колит (Е3) & 18 & 56,3 \\
\hline
\end{tabular}

Таблица 3 Частота поражения различных отделов ЖКТ у больных с БК

\begin{tabular}{|l|l|l|}
\hline \multirow{2}{*}{ Протяженность } & $\mathrm{n}=9$ \\
\cline { 2 - 3 } & $\mathrm{n}$ & $\%$ \\
\hline Илеит (L1) & 2 & 22,2 \\
\hline Колит (L2) & 2 & 22,2 \\
\hline Илеоколит (L3) & 5 & 55,6 \\
\hline
\end{tabular}

компанией “Вектор-Бест” (Россия). Количественные значения выражались в пг/мл. Для определения концентрации ФК использовали набор реагентов для иммуноферментного анализа IDK® кальпротектин (Immundiagnostik AG, Германия). При обработке данных применялась программа прикладной статистики STATISTICA. Анализ проводился посредством параметрических методов: описательная статистика - среднее значение, стандартное отклонение, определение t-критерия Стьюдента при сравнении средних величин.

\section{Результаты исследования}

Результаты определения показателей цитокинового профиля представлены в Таблице 4. Уровень ИЛ-6 у

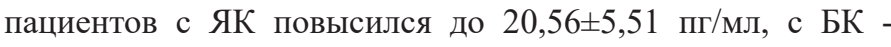
$18,64 \pm 4,70$ пг/мл. Также наблюдалось высокое значение ИЛ-8 в обеих группах, которое у больных с ЯК составило

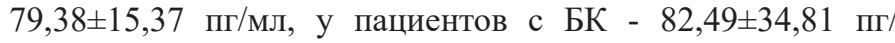
мл. Повышенные концентрации ФНО- $\alpha$ при ЯК и БК

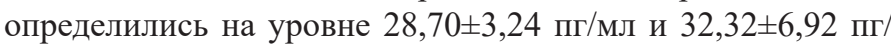
мл соответственно.

Таблица 4 Уровень цитокинов в сыворотке крови больных ЯК и БК, пг/мл

\begin{tabular}{|l|l|l|l|l|l|}
\hline № & Показатель & ЯК $(\mathrm{n}=32)$ & БК $(\mathrm{n}=9)$ & ВЗК (ЯК+БК) $(\mathrm{n}=41)$ & РИ \\
\hline 1 & ИЛ-6 & $20,56 \pm 5,51^{* *}$ & $18,64 \pm 4,70^{* *}$ & $19,65 \pm 4,44^{*}$ & $0-10,0$ \\
\hline 2 & ИЛ-8 & $79,38 \pm 15,37^{* *}$ & $82,49 \pm 34,81^{* *}$ & $80,06 \pm 13,79^{*}$ & $0,00-10,00$ \\
\hline 3 & ФНО- $\alpha$ & $28,70 \pm 3,24^{* *}$ & $32,32 \pm 6,92^{* *}$ & $28,99 \pm 2,95^{*}$ & $<8,1$ \\
\hline
\end{tabular}

Примечание: РИ - референтный интервал; *p $<0,05$ - статистическая значимость между полученными и референтными значениями; ** $>0,05$ - различия статистически не значимы между группами с ЯК и с БК.

При анализе уровня цитокинов в зависимости от протяженности поражения толстой кишки у пациентов с ЯК было выявлено увеличение концентрации ИЛ-6 и ИЛ-8 при левостороннем и тотальном поражении толстой кишки:

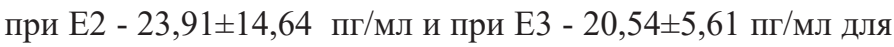

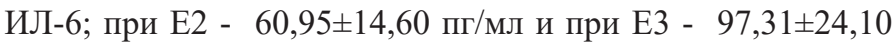
пг/мл для ИЛ-8. Необходимо подчеркнуть, что значение ИЛ-8 наблюдалось самым высоким при любой локализации 
поражения в отличие от ИЛ-6 и ФНО- $\alpha$, однако достоверная разница отмечалась только при тотальном колите $(\mathrm{p}<0,01)$. Несмотря на повышенный уровень ФНО- $\alpha$, не было получено статистически значимых различий в концентрациях данного показателя в зависимости от протяженности поражения (Таблица 5).

Таблица 5 Уровень ИЛ-6, ИЛ-8 и ФНО- $\alpha$ в зависимости от протяженности поражения толстой кишки у пациентов с ЯК, ПГ/МЛ

\begin{tabular}{|l|l|l|l|}
\hline \multirow{2}{*}{ Протяженность поражения } & ИЛ-6 & \multicolumn{2}{|l|}{ ИЛ-8 } \\
\cline { 2 - 4 } & M \pm m & $47,52 \pm 21,25^{*}$ & $28,47 \pm 9,68^{* *}$ \\
\hline Проктит Е1 $(\mathrm{n}=3)$ & $8,51 \pm 2,65^{* *}$ & $60,95 \pm 14,60^{* *}$ & $23,47 \pm 4,44^{* *}$ \\
\hline Левосторонний колит E2 (n=11) & $23,91 \pm 14,64^{* *}$ & $97,31 \pm 24,10^{*}$ & $32,39 \pm 5,29^{* *}$ \\
\hline Тотальный колит Е3 (n=18) & $20,54 \pm 5,61^{* *}$ & \\
\hline
\end{tabular}

Примечание: *p<0,01 - различия статистически значимы между группами с разной протяженностью поражения; **p $>0,05$ - различия статистически не значимы между группами с разной протяженностью поражения.

Аналогичная картина наблюдалась и в группе пациентов с БК, где также самая высокая концентрация ИЛ-8 была при тотальном колите $116,34 \pm 32,34$ пг/мл (р<0,05), что объясняется эксплицированностью острой фазы воспаления
[11]. В отличие от пациентов с ЯК, при БК отмечалась динамика уровня ФНО- $\alpha$ в зависимости от протяженности поражения. Так, концентрация ФНО- $\alpha$ достигала максимума

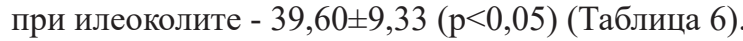

Таблица 6 БКовень

\begin{tabular}{|l|l|l|l|}
\hline Протяженность поражения & \multicolumn{2}{l|}{ ИЛ-6 } & \multicolumn{2}{l|}{ ИЛ-8 } & \multicolumn{2}{l|}{ ФНО- $\alpha$} \\
\cline { 2 - 4 } & $\mathrm{M} \pm \mathrm{m}$ & $17,50 \pm 19,09^{*}$ & $8,90 \pm 1,84^{*}$ \\
\hline Илеит (L1) (n=2) & $4,23 \pm 0,36^{*}$ & $62,86 \pm 8,78^{* *}$ & $37,95 \pm 14,50^{* *}$ \\
\hline Колит (L2) (n=2) & $27,30 \pm 15,49^{* *}$ & $116,34 \pm 32,34^{*}$ & $39,60 \pm 9,33^{*}$ \\
\hline Илеоколит (L3) (n=5) & $20,96 \pm 6,04^{*}$ & \\
\hline
\end{tabular}

Примечание: $* \mathrm{p}<0,05$ - различия статистически значимы между группами с разной протяженностью поражения; **p $>0,05$ - различия статистически не значимы между группами с разной протяженностью поражения.

Проведено сравнение значений цитокинов при различной степени активности заболевания. Как известно, индекс Мейо интегрирует клиническую и эндоскопическую активность с использованием оценки состояния слизистой оболочки по Schroeder [18]. Результаты различий уровня цитокинов в зависимости от индекса Мейо приведены в Таблице 7.

Таблица 7 Уровень цитокинов в сыворотке крови больных ЯК при различной степени активности заболевания Таблица 7 (индекс Мейо), пг/мл

\begin{tabular}{|c|c|c|c|}
\hline \multirow[t]{2}{*}{ Индекс Мейо } & ИЛ-6 & ИЛ-8 & $\Phi H O-\alpha$ \\
\hline & \multicolumn{3}{|l|}{$\mathrm{M} \pm \mathrm{m}$} \\
\hline Минимальная активность (3 - 5 баллов), n=5 & $10,94 \pm 1,82$ & $20,33 \pm 4,86$ & $18,04 \pm 1,74$ \\
\hline Умеренная степень активности (6-10 баллов), n= 27 & $22,34 \pm 4,72$ & $90,69 \pm 18,01$ & $30,64 \pm 3,86$ \\
\hline Достоверность различий, р & 0,05 & $<0,001$ & 0,005 \\
\hline
\end{tabular}

Таблица 8 Уровень цитокинов в сыворотке крови больных БК в зависимости от значения индекса Беста, пг/мл

\begin{tabular}{|c|c|c|c|}
\hline Индекс Беста & ИЛ-6 & ИЛ-8 & $\Phi Н \mathrm{H}-\alpha$ \\
\hline & $\mathrm{M} \pm \mathrm{m}$ & & \\
\hline $\begin{array}{l}\text { Легкое течение и минимальная степень активности (150-200 } \\
\text { баллов), n= } 5\end{array}$ & $12,15 \pm 4,15$ & $37,30 \pm 17,38$ & $20,04 \pm 6,74$ \\
\hline $\begin{array}{l}\text { Средняя степень тяжести и умеренная активность (200-450 } \\
\text { баллов), } \mathrm{n}=4\end{array}$ & $26,77 \pm 4,29$ & $118,64 \pm 28,31$ & $47,72 \pm 8,36$ \\
\hline Достоверность различий, р & $<0,05$ & $<0,05$ & $<0,05$ \\
\hline
\end{tabular}

Таблица 9 Уровень ФК у больных ЯК и БК, мг/кг

\begin{tabular}{|l|l|l|l|l|}
\hline Показатель & $\begin{array}{l}\text { ЯК } \\
\mathrm{n}=32\end{array}$ & $\begin{array}{l}\text { БК } \\
\mathrm{n}=9\end{array}$ & $\begin{array}{l}\text { ВЗК (ЯК+БК) } \\
\mathrm{n}=41\end{array}$ & $\begin{array}{l}\text { РИ } \\
\text { ФК }\end{array}$ \\
\hline $183,71 \pm 45,26^{* *}$ & $59,49 \pm 10,93^{* *}$ & $181,36 \pm 56,67^{*}$ \\
\hline
\end{tabular}

Примечание: РИ - референтный интервал; *p<0,05 - статистическая значимость между полученными и референтными значениями; ** $=0,01$ статистическая значимость между группами с ЯК и с БК. 
В свою очередь и у пациентов с БК был проведен анализ зависимости уровня цитокинов от степени активности заболевания с использованием индекса Беста (Crohn's Disease Activity Index, CDAI). Данные Таблицы 8 демонстрируют повышение концентрации цитокинов по мере нарастания активности воспалительного процесса $(\mathrm{p}<0,05)$.

Кроме того, у пациентов, включенных в исследование, было проведено определение ФК (Таблица 9), а также анализ его значений в зависимости от протяженности поражения (Таблица 10).

Помимо этого, у всех пациентов точно также как при оценке показателей цитокинового профиля мы проанализировали взаимосвязь между концентрацией ФК и клинико-эндоскопической активностью заболевания (Таблица 11).

Таблица 10 Уровень ФК у больных ЯК и БК в зависимости от протяженности поражения толстой кишки, мг/кг

\begin{tabular}{|l|l|l|l|}
\hline Протяженность поражения (ЯК) & $\begin{array}{l}\text { ФК (ЯК) } \\
\text { M } \pm \text { m }\end{array}$ & Протяженность поражения (БК) & $\begin{array}{l}\text { ФК (БК) } \\
\text { M } \pm m\end{array}$ \\
\hline E1 (n=3) & $74,90 \pm 26,14^{*}$ & Илеит (L1) (n=2) & $45,45 \pm 10,17^{*}$ \\
\hline E2 $(\mathrm{n}=11)$ & $113,57 \pm 52,13^{* *}$ & Колит (L2) (n=2) & $40,73 \pm 6,89^{*}$ \\
\hline E3 $(\mathrm{n}=18)$ & $194,70 \pm 50,91^{*}$ & Илеоколит (L3) (n=5) & $72,63 \pm 8,05^{*}$ \\
\hline
\end{tabular}

Примечание: *p=0,05 - различия статистически значимы между группами с разной протяженностью поражения; ** $>0,05$ - различия статистически не значимы между группами с разной протяженностью поражения.

Таблица 11 Уровень ФК у больных ЯК и БК в зависимости от клинической активности, мг/кг

\begin{tabular}{|l|l|l|l|}
\hline Индекс Мейо & $\begin{array}{l}\text { ФК (ЯК) } \\
\mathrm{M} \pm \mathrm{m}\end{array}$ & Индекс Беста & $\begin{array}{l}\text { ФК (БК) } \\
\text { М } \pm \mathrm{m}\end{array}$ \\
\hline $\begin{array}{l}\text { Минимальная активность (3 - 5 баллов), } \\
\mathrm{n}=5\end{array}$ & $86,60 \pm 19,25$ & $\begin{array}{l}\text { Минимальная активность (150-200 баллов), } \mathrm{n}= \\
5\end{array}$ & $45,60 \pm 8,93$ \\
\hline $\begin{array}{l}\text { Умеренная степень активности } \\
\text { (6-10 баллов), } \mathrm{n}=27\end{array}$ & $170,30 \pm 34,97$ & Умеренная активность (200-450 баллов), $\mathrm{n}=4$ & $71,95 \pm 9,31$ \\
\hline Достоверность различий, $\mathrm{p}$ & $<0,05$ & Достоверность различий, $\mathrm{p}$ & $\mathrm{p}=0,05$ \\
\hline
\end{tabular}

\section{Обсуждение}

За последние десятилетия терапевтические цели ВЗК эволюционировали от борьбы с симптомами до контроля активности воспаления как единственного процесса, от которого зависит течение заболевания и риск развития осложнений. В связи с этим воздействие на воспаление стало ключевой стратегией терапии, что является основанием для продолжающихся исследований по изучению маркеров активности воспаления. Нами был изучен цитокиновый профиль, включавший ИЛ-6, ИЛ-8 и ФНО- $\alpha$, а также определен уровень фекального кальпротектина у пациентов с ЯК и БК.

При определении концентрации цитокинов в сыворотке крови уровни ИЛ-6, ИЛ-8 и ФНО- $\alpha$ у пациентов с ВЗК превышали референтные значения (Таблица 4), при этом различия в значениях ИЛ-6, ИЛ-8 и ФНО- $\alpha$ между двумя группами пациентов с ЯК и БК были статистически незначимы $(\mathrm{p}>0,05)$, что подтверждает результаты многочисленных иммунологических исследований, доказывающих общность патогенеза двух фенотипических форм единого ВЗК $[4,5]$.

Следующий этап заключался в анализе значений ИЛ6, ИЛ-8 и ФНО- $\alpha$ у пациентов с различной локализацией поражения толстой кишки. Как при ЯК, так и при БК наиболее высокий уровень был характерен для ИЛ-8 при любой протяженности поражения, достигая достоверно значимых различий при тотальном колите. Стоит отметить, что в ряде исследований по изучению уровня цитокинов в биоптатах толстой кишки были установлены наиболее высокие концентрации ИЛ-8 по сравнению с ИЛ-6 и ФНО- $\alpha$ [19]. Результаты нашего наблюдения также позволяют подчеркнуть его ведущую роль в развитии деструктивноязвенного воспаления толстой кишки. Отсутствие значимой разницы между группами с разной протяженностью поражения объясняется малым объемом выборки больных ЯК с проктитом и левосторонним колитом, а также пациентов с БК.

В исследуемых группах было установлено, что с повышением степени активности заболевания наблюдается увеличение концентрации изучаемых цитокинов. Так, концентрация ИЛ-6 и ИЛ-8 была достоверно выше в группе ЯК с умеренной активностью в отличие от группы с минимальной активностью: для ИЛ-6 $10,94 \pm 1,82$ и $22,34 \pm 4,72$ ( $\mathrm{p}=0,05)$; для ИЛ- 8 - 20,33 $\pm 4,86$ и $90,69 \pm 18,01(\mathrm{p}<0,001)$. Также и в отношении уровня ФНО- $\alpha$ наблюдалась значимая разница в двух группах с преобладанием значения у пациентов с умеренной степенью активности (6-10 баллов) - 30,64 $\pm 3,86$ пг/мл по сравнению с пациентами с минимальной активностью (3 - 5 баллов) $18,04 \pm 1,74$ пг/мл ( $\mathrm{p}=0,005)$. У пациентов с БК: концентрация ИЛ-6 в группе с легким течением и минимальной степенью

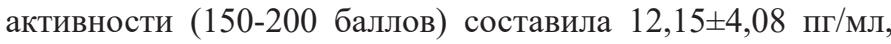
в то время как в группе со средней степенью тяжести и умеренной активностью (200-450 баллов) - 26,77 $\pm 4,29$ пг/ мл $(\mathrm{p}<0,05)$. Уровень ИЛ-8 в обеих группах был на уровне $37,30 \pm 17,38$ и $118,64 \pm 28,31$ соответственно $(\mathrm{p}<0,05)$. Отмечалось значительное повышение концентрации ФНО- $\alpha$ у пациентов со средней степенью тяжести и умеренной активностью до 47,72 $\pm 8,36$ пг/мл, что достоверное превысило значение этого показателя в сравнении с группой пациентов с легким течением и минимальной степенью активности - 20,04 $\pm 6,74$ ( $<<0,05)$ (Таблица 8). Несмотря на определенные ограничения в исследовании, такие как малое количество пациентов и однократный анализ маркеров, результаты анализа продемонстрировали статистическую разницу в значениях показателей цитокинового профиля у 
пациентов с разной степенью активности заболевания, что позволяет предположить возможность использования ИЛ-6, ИЛ-8 и ФНО- $\alpha$ в качестве диагностических маркеров ВЗК.

Подобная оценка была проведена и с неинвазивным маркером воспаления - фекальным кальпротектином. Как видно из Таблицы 9, уровень ФК значительно повышен у всех пациентов с ВЗК - 181,36 $\pm 56,67$ мг/кг, при этом у пациентов с ЯК его концентрация достоверно выше по сравнению с пациентами с БК: $183,71 \pm 45,26$ мг/кг и $59,49 \pm 14,93$ мг/кг $(p=0,01)$. У пациентов с ЯК самое высокое значение ФК было получено при тотальном колите $194,70 \pm 50,91$ мг/кг $(\mathrm{p}=0,05)$. В группе пациентов с БК максимальный уровень прослеживался при илиоколите $72,63 \pm 8,05$ ( $\mathrm{p}=0,05)$ (Таблица 10). Кроме того, концентрация ФК увеличивалась по мере повышения значений клиникоэндоскопических индексов. Так, в группе обследуемых

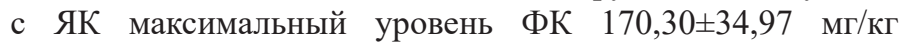
отмечался при умеренной степени активности (6-10 баллов), значимо превосходя данный показатель в два раза по сравнению с группой пациентов с минимальной

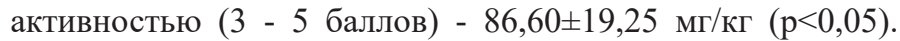
Аналогичные результаты наблюдались и в группе больных с БК. У пациентов с умеренной активностью (200-450 баллов) уровень ФК достоверно больше по сравнению с пациентами с минимальной активностью (150-200 баллов), а именно были получены следующие значения ФК в двух подгруппах:

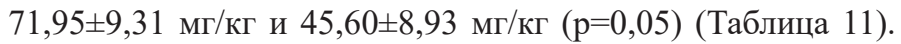
Полученные результаты согласуются с литературными данными, доказывающие диагностическую ценность ФК в качестве показателя воспалительной активности ВЗК [14].

\section{Выводы}

Результаты

проведенного

исследования

продемонстрировали повышение концентраций ИЛ-6, ИЛ-8 и ФНО- $\alpha$ у пациентов с ЯК и БК, значительно превосходя референтные значения. При усилении активности воспалительного процесса наблюдалось достоверное повышение уровней ИЛ-6, ИЛ-8 и ФНО- $\alpha$. Определение уровня ФК в зависимости от локализации поражения и активности процесса подтвердило его значимость в оценке протяженности поражения толстой кишки и диагностике активности ЯК и БК в разные фазы течения заболевания, что соответствует положениям последнего пересмотра Европейского общества по изучению БК и ЯК $[16,17]$.

Disclosures: There is no conflict of interest for all authors.

\section{Литература}

1. Ng SC, Shi HY, Hamidi N, Underwood FE, Nang W, Benchimol EI, Panaccione R, Ghosh S, Wu JCY, Chan FKL, Sung JJY, Kaplan GG. Worldwide incidence and prevalence of inflammatory bowel disease in the 21 st century: a systematic review of population-based studies. Lancet. 2018; 390(10114):2769-2778. https://doi.org/10.1016/S0140-6736(17)32448-0

2. Guan Q, Zhang J. Recent Advances: The Imbalance of Cytokines in the Pathogenesis of Inflammatory Bowel Disease. Mediators of Inflammation. 2017; 2017:4810258. https://doi.org/10.1155/2017/4810258

3. Ivashkin VT, Lapina TL. Gastroenterologiya. Natsional'noe rukovodstvo: kratkoe izdanie (National guideline: short edition) [in Russian]. GEOTAR-Media. 2015; 480.

4. Loddo IN, Romano CC. Inflammatory bowel disease: genetics, epigenetics, and pathogenesis. Frontiers in Immunology. 2015; 6:551. https://doi.org/10.3389/fimmu.2015.00551

5. Neurath MF. Cytokines in inflammatory bowel disease. Nature Reviews Immunology. 2014; 14(5):329-342. https://doi. org/10.1038/nri3661

6. Souza HS, Fiocchi CV. Immunopathogenesis of IBD: current state of the art. Nature Reviews Gastroenterology \& Hepatology. 2016; 13(1):13-27. https://doi.org/10.1038/nrgastro.2015.186

7. Takać B., Mihaljević S., Śtefanić M., Glavaš-Obrovac L., Kibel A., Samardžija M. Importance of Interleukin 6 in Pathogenesis of Inflammatory Bowel Disease. Coll. Antropol. 2014; 38(2): 659-664.

8. Locksley RM, Killeen NN, Lenardo MJ. The TNF and TNF receptor superfamilies: integrating mammalian biology. Cell. 2001; 104:487-501. https://doi.org/10.1016/S0092-8674(01)00237-9

9. Müzes GM, Molnár BN, Tulassay ZF. Changes of the cytokine profile in inflammatory bowel diseases. World Journal of Gastroenteroly. 2012; 18(41):5848-5861. https://doi.org/10.3748/wjg.v18.i41.5848

10. Murch SR, Braegger CD, Walker-Smith JA, MacDonald T. Location of tumour necrosis factor alpha by immunohistochemistry in chronic inflammatory bowel disease. Gut. 1993; 34:1705-1709. https://doi.org/10.1136/gut.34.12.1705

11. Cotton JA, Platnich JM, Muruve DA, Jijon HB, Buret AG, Beck PL. Interleukin-8 in gastrointestinal inflammation and malignancy: induction and clinical consequences. International Journal of Interferon, Cytokine and Mediator Research. 2016; 8:13-34. https:// doi.org/10.2147/IJICMR.S63682

12. Ljuca F, Gegic A, Salkic NN, Pavlovic-Calic N. Circulating cytokines reflect mucosal inflammatory status in patients with Crohn's disease. Digestive Diseases and Science. 2010; 55(8):2316-26. https://doi.org/10.1007/s10620-009-1016-9

13. Nancey S, Hamzaoui N, Moussata D, Graber I, Bienvenu J, Flourie B. Serum interleukin-6, soluble interleukin-6 receptor and Crohn's disease activity. Digestive Diseases and Science. 2008; 53(1):242-7. https://doi.org/10.1007/s10620-007-9849-6

14. Vrabie R, Kane S. Noninvasive Markers of Disease Activity in Inflammatory Bowel Disease. Gastroenterology \& Hepatology. 2014; 10(9):576-584.

15. Matusiewicz M, Neubauer K, Bednarz-Misa I, Gorska S, Krzystek-Korpacka M. Systemic interleukin-9 in inflammatory bowel disease: Association with mucosal healing in ulcerative colitis. World J Gastroenterol. 2017; 23(22):4039-4046. https://doi. org/10.3748/wjg.v23.i22.4039

16. Magro F., Gionchetti P., Eliakim R. et al. Third European Evidence-based Consensus on Diagnosis and Management of Ulcerative Colitis. Part 1: Definitions, Diagnosis, Extra-intestinal Manifestations, Pregnancy, Cancer Surveillance, Surgery, and Ileo-anal Pouch Disorders. Journal of Crohn's and Colitis. 2017; 649-670. https://doi.org/10.1093/ecco-jcc/jjx008 
17. Gomollón F., Dignass A., Annese V. et al. 3rd European Evidence-based Consensus on the Diagnosis and Management of Crohn's Disease 2016: Part 1: Diagnosis and Medical Management. Journal of Crohn's and Colitis. 2017; 3-25. https://doi.org/10.1093/ ecco-jcc/jjw168

18. Ivashkin VT, Shelygin YA, Abdulganieva D I, Abdulkhakov RA, Alekseeva O P, Achkasov SI et al. Rekomendatsii Rossiiskoi gastroenterologicheskoi assotsiatsii i Assotsiatsii koloproktologov Rossii po diagnostike i lecheniyu vzroslykh bol'nykh yazvennym kolitom (Guidelines of the Russian Gastroenterological Association and the Association of Coloproctologists for diagnosis and treatment of adults with ulcerative colitis) [in Russian]. Rossiiskii zhurnal gastroenterologii, gepatologii, koloproktologii. 2015; 1:48-65.

19. Konovich EA, Shirokih KE, Halif IL, Shapina MV. Citokiny tolstoj kishki pri tjazheloj forme jazvennogo kolita (The colon cytokines at acute ulcerous colitis) [in Russian]. Novosti koloproktologii. 2016; 1:93-98.

How to cite this article: Ainur Doszhan, Roza Bektayeva, Aiman Galiyeva, Kapura Adrissova. Determination of cytokine profile and fecal calprotectin in patients with inflammatory bowel disease of different activity degree [in Russian]. J Clin Med Kaz. 2019; 2(52):23-29 